\title{
A magyar városhálózat stabilitása és változása
}

\section{Stability and change in the Hungarian city network}

\section{RECHNITZER JÁNOS, PÁTHY ÁDÁM, BERKES JUDIT}

RECHNITZER János: tanszékvezető egyetemi tanár, Széchenyi István Egyetem, Regionális-Tudományi és Közpolitikai Tanszék, Győr; rechnj@sze.hu

PÁTHY Ádám: egyetemi tanársegéd, Széchenyi István Egyetem, Regionális-Tudományi és Közpolitikai Tanszék, Győr; pathya@rkk.hu

BERKES Judit: PhD-hallgató, Széchenyi István Egyetem, Regionális-Tudományi és Közpolitikai Tanszék, Győr; berkes.judit@sze.hu

KULCSSZAVAK: innováció, versenyképesség, városhálózat, térszerkezet

ABSZTRAKT: A települések innovációs képességének vizsgálatáról számos hazai munka számolt be az elmúlt közel húsz év során. Ezek közül alig találkozhatunk komplex, a magyar városhálózat teljes egészére kiterjedő vizsgálatokkal. Ennek fontosságától nem tekinthetünk el, hiszen az elemzés során kapott eredmények alapot jelenthetnek különböző, a városhálózat sajátos jellege alapján meghatározott stratégiák kidolgozására.

Tanulmányunk alapját egy 2005-ös innovációspotenciál-vizsgálat jelenti, melynek módszertanát megtartva tárjuk fel a hazai városhálózat tagozódását, az egyedi változók öt különböző dimenzióba történő rendezésével. Az öt főkomponens a következő: gazdaság, iskolázottság és menedzsment, társadalmi aktivitás, humánerőforrás, innováció.

A módszer lehetőséget adott arra, hogy felderítsük a városhálózat belső differenciáltságát, illetve a dimenziók mentén betekintést nyerünk abba, hogy a városhálózat csoportjai milyen mértékü innovációs képességgel rendelkeznek. A főkomponenseket 327 város adatainak figyelembevételével alakítottuk ki, ebben nem szerepelnek Budapest, valamint a 2013 júliusában városi rangot elnyert 18 város mutatói.

A kapott eredmények arról is tanúskodnak, hogy a területi egyenlőtlenség tovább növekszik. A városok közötti különbségek mérséklődtek, azonban az egyes dimenziók közötti szakadék tovább nőtt. A jól teljesítő városok esetében sem feltétlenül találkozik a gazdasági és innovációs potenciál.

János RECHNITZER: professor, head of department, Department of Regional Studies and Public Policy, Széchenyi István University, Győr; rechnj@sze.hu

Ádám PÁTHY: assistant lecturer, Department of Regional Studies and Public Policy, Széchenyi István University, Győr; pathya@rkk.hu

Judit BERKES: PhD student, Department of Regional Studies and Public Policy, Széchenyi István University, Győr; berkes.judit@sze.hu

KEYWORDS: innovation, competitiveness, city network, spatial structure

ABSTRACT: A considerable amount of literature has been published in Hungarian on the settlements' innovation capability in the past twenty years. However, among these studies we

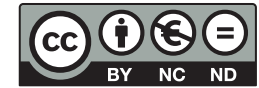


can barely find a complex examination that would embrace the entire Hungarian city network. We cannot set aside its importance, since the situation exposed and the results revealed by such an examination could serve as a basis for evolving different strategies defined by the peculiar features of the city network.

The basis for our study is an analysis of innovation potential carried out in 2005. Sticking to its methodological structure, we made an attempt to reveal the dispersion of Hungarian city networks by organizing the unique variables into five dimensions. These five dimensions are as follows: economy, education and management, social activity, human resources, innovation.

This method made it possible to explore the differences within the city networks, as well as to shed light on the degree of innovational capabilities of the methodologically well-defined groups of city networks. The dimensions were formed based on the data from 327 cities. The sample does not include the indicators of Budapest and other 18 cities which gained urban status in July 2013.

We used cluster analysis based on the principal component scores to determine homogeneous groups of cities. Twenty-five cities with the best complex indicators were separated and a hierarchical cluster analysis was done on them. Groups of the remaining cities were determined by the $k$-means cluster analysis. Human resources and innovation indicators played a great role in the stratification of the twenty-five "elite" cities. Six groups were identified among them as follows: regional centers with complex structure; regional centers with economic emphasis; cities with research and development dominance; suburban economic centers; cities with significant knowledge base and higher education; sub-regional centers with balanced structure. The remaining 302 cities were classified into four clusters. Here we can observe a "second tier" in the city network, consisting of 37 cities. Availability of human resources and innovation is also relevant in this category, but clusters below this level - containing mostly small towns and "quasi-towns" with deficient central functions - are determined along the primary economic and social factors.

The results also prove that regional inequalities are constantly increasing. Differences between cities decreased slightly, however, the gap between the dimensions became even wider. The economic and innovation potential do not necessarily meet in the case of well-performing cities.

\section{Bevezetés}

A hazai regionális kutatások egyik fontos területe a településhálózat, s azon belül a városrendszerek elemzése. A városok meghatározó szerepet töltenek be a területi folyamatokban, hiszen koncentrált erőforrásokkal, azok valamilyen kombinációjával rendelkeznek, s így generálói a térszerkezet alakításának. Kutatásunk azt vizsgálja, hogy egy vagy több domináns gazdasági szektor által formált városi térben milyen fejlődési sajátosságok mutathatók ki. Emellett kíváncsiak vagyunk arra, hogy a városrendszer elemeit, alrendszereit, térbeli megjelenését és kiterjedését ezek a gazdasági koncentrációk és az azokhoz szervesen kapcsolódó tevékenységek, funkciók, továbbá az azokat megtestesítő intézmények miként képesek alakítani.

A kutatás számos dimenziója közül az egyik, hogy áttekintjük a hazai városhálózat változási irányait. Egyrészt keressük a hálózatalakítás meghatározó tényezőit, másrészt vizsgáljuk az összetartozó, azonos jellegzetességeket mutató csoportokat, s végül pozicionáljuk az egyes városokat, regisztrálva azok elmozdulásait. Az időbeliségre is törekszünk, hiszen az ezredforduló időszakára 
vonatkozó elemzéseket (Grosz, Rechnitzer 2005; Horváth 2006) ismételjük meg, minimális kiegészítéssel. A vizsgálatok reprodukálásával célunk a változások bemutatása. Leírjuk azokat a tényezőket, amelyek mozgatták a magyar városhálózat egészét, s azokból kiemelten a nagyvárosokat, térségszervező központokat, valamint érzékeltetjük az esetleges az egyes alakító tényezők szerkezeti átrendeződését. Meghatározzuk az azonos fejlődést mutató csoportokat, megadva azok térbeli elhelyezkedését, tagjait, jellemzőit.

\section{A városkutatás hazai irányainak rövid áttekintése}

A hazai regionális tudomány több szinten és dimenzióban foglalkozott a várossal mint meghatározó területi egységgel, a városi rendszerekkel, hálózatokkal. A kutatások hatására - vélhetően - a területi politika, s annak dokumentumai is növekvő hangsúlyt helyeztek a városok fejlesztésére, azok funkcióinak meghatározására, majd lehetséges alakítási irányaik kijelölésére.

Rövid áttekintésünkben a hangsúlyt a városkutatás főbb irányaira helyezzük, kiemeljük azokat az elemzéseket, amelyek a hálózatalakításban adhatnak eligazítást, valamint a nagyvárosi szerkezethez, annak egészéhez, csoportjaihoz vagy egyes tagjaihoz köthetők.

Az első csoportba soroljuk a városok kialakulásával, fejlödésével, az urbanizációs folyamat elemeivel, megjelenési formáival foglalkozó műveket. Az új klasszikus mủ Enyedi György (2012) monográfiája, amely az urbanizáció világméretű jelenségének izgalmas leírását adja a különböző nagytérségekben, más és más fejlődési pályákon. Nagy hangsúlyt helyez a városhálózatokra, azok kialakulására és fejlödési sajátosságaira, de részletesen nem tárgyalja a magyar jellegzetességeket. Ennek történeti metszeteit, valamint annak alakulását tekinti át Beluszky Pál (1999) szintén klasszikusnak tekinthető munkájában, ahol kitér a regionális funkcióval rendelkező városok hálózatára, az annak változását előidéző történelmi, gazdasági tényezőkre. Viszonylag kevés elemzés foglalkozott a hazai nagyvárosok európai és közép-európai összevetésével, e hálózatokban elfoglalt helyüknek a meghatározásával (Enyedi 2010; Horváth 1998; Tagai 2010).

Míg Kelet-Közép-Európa városhálózatának fejlődési irányai elhanyagoltak a hazai irodalomban, addig a városi társadalom és rendszer irányításának, szervezésének kérdései erősen felülreprezentáltak. Kiemelkednek azok az elemzések, amelyek a nagyvárosi társadalmak átalakulást tekintik át, kitérve a legfontosabb mozgató tényezőkre (Szirmai 2009, 2013). A városi rendszerek kormányzása (Pálné Kovács 2010), a város és vidék vagy agglomerációk együttműködésének alakulása, a térszervezés intézményi kereteinek alakulása érdemleges eredményeket mutatott fel (Somlyódyné Pfeil 2012). Izgalmas vita zajlott a várossá válásról, de egyben a városi rendszerek fejlődését meghatározó tényezőkről is (Csapó, Kocsis 2008; Dövényi 2009; Kulcsár 2008; Pirisi 2009; Pirisi, 
Trócsányi 2009; Tóth 2008). Kutatásunk szempontjából e blokk tanulságai abban álltak össze, hogy egyrészt a városi társadalom minél pontosabb leírására kell törekednünk, s az intézményi keretek jellege nem elégséges a hálózatok és azok egyes csoportjainak összehasonlításához. Valamint azt is elfogadtuk, hogy a városi funkciók standard, hagyományos elemei mellett egyre több új tényező jelenik meg, amelyek egzakt leírása még számos akadályba ütközik. S végül magyarázatot kaptunk arra, hogy a magyar városhálózat nagy tömegét funkcióhiányos kisvárosok teszik ki, amelyek döntően a rendszerváltozás után nyerték el a városi rangot, s közülük igen kevesek emelkedtek ki.

A városi funkciók (erőforrások, intézmények, szerkezetek) és azok térbeli hatásait elemző, alapos módszertani ismereteket nyújtó kutatások (Bajmócy, Kiss 1999; Nagy 2011; Szigeti 2002; Tóth 2011) segítettek a regionális szerepkörök egyértelmü elhatárolásában, azoknak a funkcióknak a kiválasztásában vagy megerősítésében, amelyek a városok térbeli hatásait jól közvetítik.

A következő blokkba soroltuk azokat az irodalmakat és elemzéseket, amelyek a városi hálózatokra vonatkoztak. A hálózati elemzéseken belül több témakört lehet elkülöníteni. Az első a fejlesztési stratégiák csoportja, ahol az alapvető kérdés, hogy milyen szerkezetek kialakítása történjen meg a jövőben, a hálózatban; annak egyes csomópontjai (regionális központok) milyen szereppel és funkciórendszerrel rendelkezzenek, s milyen legyen a viszony Európa más nagyközpontjaival és a többi magyar várossal (Barta 2009; Faragó 2006, 2008, 2009). Ehhez kapcsolódik a regionális központok értelmezése, meghatározása, a térbeli növekedési pólusok leírása, azok működésének körbejárása és a kapcsolódó fejlesztések meghatározása (Horváth 2007; Lengyel 2007; Rechnitzer 2007). A városhálózat szerkezeti sajátosságainak elemzése a másik nagy vizsgálati terület, ebben két irányt különíthetünk el: az egyik az általános szerkezeti elemzés, amikor a fejlődési irányok értékelése segíti a tervezést (Salamin, Radvánszki, Nagy 2008), a másik a szerkezetet alakító nagyvárosok, központok helyzetének, funkcióinak vizsgálata és ebből a hálózatszervezés irányainak számbavétele (Csomós 2013; Tóth, Nagy 2013).

Végül, de nem utolsósorban témánk szempontjából meghatározó kérdések a városhálózat alakításában az innovációk, a megújitások megjelenése, illetve az azokat jellemző tényezők és a szerkezetet alakító további faktorok (gazdaság, társadalom, népesség, intézmény) kapcsolata, kölcsönös egymásrautaltsága (Grosz, Rechnitzer 2005; Lengyel, Rechnitzer 2000; Rechnitzer 1993; Rechnitzer, Csizmadia, Grosz 2004). A kapcsolatelemzések lehetőséget adtak arra, hogy típusokat határoljunk le, keresve azokat az összetartozó, azonos fejlődési pályát mutató városokat, amelyekben a vizsgált tényezők sokasága valamilyen mértékben egyezik, s ezzel hasonló szerepük lehet a hálózat egészének alakításában, de a térszerkezet formálásában is.

Elemzésünk célja az időbeliség regisztrálása, nemcsak a hálózat egészének bemutatása, annak egy időpontban történő felvétele, hanem a változás megragadása. Annak kimutatása, hogy a városhálózat milyen irányban alakult a rend- 
szerváltozás időszakában (1991-1992), az ezredfordulót megelőző időszakban (1997-1998), annak első évtizede elején (2002-2003), végül a jelenlegi évtized első éveiben (2011-2012).

Vélhetően rövid ez az időszak, hiszen bár a városhálózat számos taggal bővült, de nagyon lassan mozdul el, annak stabil elemei új funkciókat csak idővel alakítanak ki, azok hatásai erősen megkésve - néha követhetetlenül - jelentkeznek. A helyezések, az összetartozó csoportok, a pozíciók alakulását az adatbázisok - még ha törekedtünk is az időbeli és tartalmi egységesítésre - erősen befolyásolják, azok részben új és új elemekkel, s a régiek pedig változó tartalmakkal állíthatók elő. Az elemzéseink tehát egy időszakra vonatkozó helyzetképet, egy újabb felvételt adnak a térszerkezetet döntően alakító centrumok hálózatáról. A visszautalások, az időbeli összevetések a lehetséges pályák irányait adják meg, és persze az azokat formáló tényezőket. A hálózat alakulásának mozgatóelemeit számba vettük tanulmányunkban, s magyar vonatkozásban értelmezhető összefüggéseket fogunk bemutatni.

\section{Az adatbázis}

Tanulmányunk elsősorban arra tesz kísérletet, hogy a Grosz és Rechnitzer (2005) által publikáltt innovációspotenciál-vizsgálat megismétlésével bemutassa a hazai városhálózat tagozódását a versenyképesség és az innovációs potenciál alapján, figyelemmel követve az elmúlt évtized változásait. Ezen túlmenően az elemzések során fontosnak tartottuk azt is, hogy további, részletesebb feltárásokkal kiindulópontokat adjunk meg mind a felhasznált indikátorokra, mind pedig az alkalmazott módszerekre vonatkozóan. Kerestük a lehetőségeket, hogy még pontosabban és árnyaltabban alakítsuk ki a különböző várostípusokat, továbbá határozottabban rávilágítsunk a tudásteremtés és tudáskiaknázás közötti kapcsolatokra vagy azok hiányára.

Ennek megfelelően megtartottuk a korábbi struktúrát, az öt tematikus fökomponensbe rendezett változókat. Az indikátorkészlet felépítése is megegyezik a korábbi elemzéssel, a változók tartalma és a fajlagos mutatók kialakításának módszere néhány kivétellel szintén azonos elvet követ. Egy változó - a szolgáltatásokban foglalkoztatottak aránya - maradt ki a megismételt vizsgálatból, mivel az adat nem áll rendelkezésünkre települési szinten, és nincs olyan hasonló tartalmú indikátor, amellyel érdemben helyettesíteni tudtuk volna. Egy mutató tartalma jelentősen változott, a gazdasági főkomponens esetében indokoltnak tartottuk a távbeszélő-fővonalak számának lecserélését a relevánsabb szélessávúinternet-előfizetésekkel. Apróbb változtatásnak tekinthető még, hogy a társadalmi aktivitás fókomponensben egy népszavazási (európai uniós csatlakozás) részvételi arány helyett a parlamenti választások részvételi arányát használtuk. 
Bizonyos esetekben az adattartalmat csak kismértékben érintő terminológiai változások voltak. A főiskolai és egyetemi karok esetében a karnak nem minősülő székhelyen kívüli képzések nem szerepelnek az adatok között, a jogi személyiségű vállalkozások száma esetében nem a működő, hanem a regisztrált

1. táblázat: A fókomponensek és az azokat alkotó mutatók

Indicators used in the analysis sorted by principal components

\begin{tabular}{|c|c|c|}
\hline Változó & Kommunalitás & Súly \\
\hline \multicolumn{3}{|l|}{ Gazdasági fókomponens (53\%-os sürités) } \\
\hline Foglalkoztatottak aránya a lakónépességből (\%), 2011 & 0,77 & 0,86 \\
\hline Személygépkocsik száma 1000 lakosra, 2011 & 0,77 & 0,78 \\
\hline Adófizetők aránya a lakónépességen belül (\%), 2011 & 0,67 & 0,77 \\
\hline Szja-alap egy lakosra (1000 Ft/fó), 2011 & 0,90 & 0,93 \\
\hline Szélessávúinternet-előfizetések száma 1000 lakosra, 2011 & 0,80 & 0,90 \\
\hline Működő jogi személyű vállalkozások száma 1000 lakosra, 2011 & 0,55 & 0,74 \\
\hline Munkanélküliek aránya a lakónépességből (\%), 2011 & 0,66 & 0,80 \\
\hline Inaktív keresők aránya a lakónépességből (\%), 2011 & 0,56 & 0,56 \\
\hline Helyi iparűzési adó egy lakosra (1000Ft/fö), 2011 & 0,42 & 0,62 \\
\hline Ügyvédek száma 10000 lakosra, 2011 & 0,42 & 0,48 \\
\hline Regisztrált egyéni vállalkozások száma 1000 lakosra, 2011 & 0,80 & 0,20 \\
\hline \multicolumn{3}{|l|}{ Iskolázottság és menedzsment fökomponens (88\%-os sürités) } \\
\hline Vezető és értelmiségi foglalkozásúak az összes foglalkoztatottból (\%), 2011 & 0,90 & 0,95 \\
\hline Egyetemi, főiskolai végzettségű foglalkoztatottak aránya az összes & 0,93 & 0,96 \\
\hline \multicolumn{3}{|l|}{ foglalkoztatottból (\%), 2011} \\
\hline Egyéb szellemi foglalkozásúak aránya az összes foglalkoztatottból (\%), 2011 & 0,82 & 0,90 \\
\hline \multicolumn{3}{|l|}{ Társadalmi aktivitás fökomponens (56\%-os sürités) } \\
\hline Részvételi arány a 2010-es országgyülési választások első fordulójában (\%) & 0,50 & 0,71 \\
\hline Szja nonprofit 1\% felajánlása egy lakosra (Ft), 2011 & 0,53 & 0,73 \\
\hline Nonprofit szervezetek száma 1000 lakosra (db), 2011 & 0,62 & 0,79 \\
\hline Helyi nyilvánossági fórumok összetettsége & 0,60 & 0,78 \\
\hline \multicolumn{3}{|l|}{ Humánerőforrás fökomponens (56\%-os sürités) } \\
\hline Vezető oktatók aránya az összes oktatón belül (\%), 2010 & 0,70 & 0,76 \\
\hline Főiskolai-egyetemi karok száma (db) & 0,80 & 0,86 \\
\hline Középiskolák száma (db) & 0,84 & 0,83 \\
\hline Felsőfokú intézményekben tanulók száma 1000 főre, 2011 & 0,69 & 0,82 \\
\hline MTA köztestületi tagok száma 10000 lakosra, 2013 & 0,96 & 0,75 \\
\hline A felsőfokú végzettséggel rendelkezők a 25 év felettiek között (\%), 2011 & 0,48 & 0,66 \\
\hline Felnőttoktatási központok száma 10000 lakosra, 2013 & 0,33 & 0,44 \\
\hline \multicolumn{3}{|l|}{ Innovációs fókomponens (77\%-os sürités) } \\
\hline Innovatív kezdeményezések száma 2003-2013 között (db) & 0,87 & 0,93 \\
\hline Bejegyzett domainszerverek száma (db), 2012 & 0,79 & 0,89 \\
\hline K+F-vállalkozások száma (db), 2012 & 0,87 & 0,93 \\
\hline Az innovációs és K+F-intézményhálózat összetettségi mutatója & 0,56 & 0,75 \\
\hline
\end{tabular}


vállalkozásokból indultunk ki. A foglalkozási beosztások indikátorai a FEOR osztályozási rendszer adatai alapján készültek, mivel az adatbázis összeállításának, illetve jelen tanulmány megírásának időpontjában nem álltak rendelkezésünkre a 2011-es népszámlálás részletes, települési szintű foglalkoztatási adatai. Az 1. táblázatban adjuk közre a felhasznált indikátorok listáját a főkomponensek szerint rendezve.

\section{Az elemzés módszere és a változók értékelése}

A vizsgálat első lépésében a tematikus dimenziókba sorolt változókból főkomponenseket készítettünk. A főkomponensek megtartása nem előre meghatározott sajátértékküszöb alkalmazásával történt, hanem minden esetben egy változót tartottunk meg (két dimenzió - gazdaság, humánerőforrás - esetében 2-2 főkomponens maradt, amelyek sajátértéke 1 felett volt, de mindkét esetben csak a legmagasabb magyarázóerővel rendelkezőt tartottuk meg).

A főkomponensek kialakításánál 327 város adatait vettük figyelembe, nem szerepelnek Budapest, valamint a 2013 júliusában városi rangot elnyert 18 város mutatói. A fókomponenseket alkotó változók között vegyesen találhatók fajlagos, illetve abszolút indikátorok. A főkomponensek pontszámai olyan standardizált mutatók, amelyek lehetővé teszik a különböző dimenziók együttes osztályozását.

A főkomponensek kialakításakor meggyőződhettünk arról, hogy az előző vizsgálat során alkalmazott indikátorkészlet a városhálózat jelenlegi állapotára is érvényes. A teljes variancia fökomponensek által magyarázott hányadosaiban az előző vizsgálathoz hasonló értékeket találtunk a társadalmi aktivitás, a humánerőforrás és az innovációs főkomponens esetében. A gazdasági főkomponens magyarázóereje az új adatokkal szignifikánsan alacsonyabb (53\%-ra csökkent a 62\%-kal szemben), míg az iskolázottság és a menedzsment főkomponens esetében magasabb (88\% a 79\%-kal szemben, de ez jelentős mértékben az új modellből hiányzó mutatónak tudható be).

A fókomponensek alapvető adatait elemezve látható, hogy a skálák terjedelme és azok eloszlásai az egyes dimenziókban különböznek (2. táblázat). A gazdasági és iskolázottsági - illetve bizonyos mértékben a társadalmi aktivitás fókomponensek esetében a normálishoz hasonló eloszlásokkal találkozhatunk, míg a humánerőforrás, de fóként az innováció dimenziójában ehhez képest jelentős torzulások lépnek fel. Az innovációs főkomponensnél a korábbi vizsgálatban is tapasztalt nagy terjedelem, illetve magas csúcsossági mutató a jelenlegi adatokban még egyenlőtlenebb eloszlású.

A gazdasági fókomponens esetében az átlagpontszám - a fókomponens tulajdonságai alapján nulla - mentén tulajdonképpen pontosan kettéoszlik a városhálózat, a szórástávolságon kívüli városok száma pozitív és negatív irányban 
2. táblázat: A főkomponensek alapvető eloszlási mutatói Dispersion indicators of principal components

\begin{tabular}{lccccc}
\hline \multicolumn{1}{c}{ Jellemzók } & Gazdaság & Iskolázottság & Társadalmi aktivitás & Humánerőforrás & Innováció \\
\hline Medián & 0,04 & $-0,15$ & $-0,11$ & $-0,30$ & $-0,29$ \\
Ferdeség & 0,10 & 0,52 & 0,61 & 3,72 & 5,44 \\
Csúcsosság & $-0,30$ & $-0,13$ & 0,30 & 16,02 & 40,15 \\
Minimum & $-2,38$ & $-2,15$ & $-2,07$ & $-0,66$ & $-0,50$ \\
Maximum & 2,93 & 3,25 & 4,32 & 6,40 & 10,09 \\
Terjedelem & 5,31 & 5,40 & 6,39 & 7,05 & 10,59 \\
Átlag feletti (db) & 169 & 150 & 151 & 75 & 86 \\
\hline Szórástávolságon kívül elhelyezkedó városok & 50 & 58 & & \\
Alul $(\mathrm{db})$ & 53 & 58 & 54 & 30 & 0 \\
Felül $(\mathrm{db})$ & 52 & 58 & & & \\
\hline
\end{tabular}

egyenlőnek tekinthető. Hasonló a helyzet az iskolázottság és a társadalmi aktivitás főkomponensnél is. Ezek a dimenziók „megfelelően” viselkednek a városok rangsorolásának szempontjából.

A fentiekben már jellemzett humánerőforrás és főként az innovációs fökomponens esetében többféle ok húzódik meg a normálistól jelentősen eltérő megoszlások mögött, ezek közül a két legfontosabb:

- a fókomponensek kialakitásánál felhasznált indikátorok jellege: míg az első három főkomponenst alkotó változók egy kivételével fajlagos mutatók voltak, addig a humánerőforrás főkomponens esetében két abszolút mutatót is felhasználtunk, az innovációs pedig csak ilyeneket tartalmaz;

- a mutatók tartalma: a két fókomponens esetében az azokat alkotó indikátorok jelentős része erősen polarizált. Ilyenek elsősorban a felsőfokú intézményekre vonatkozó adatok, amelyek értelemszerűen nulla értéket vesznek fel azon városokban, amelyek nem rendelkeznek ilyen intézménnyel. Az innovációs mutatókban is jelentős koncentráció tapasztalható, ami világosan kirajzol egy elitkategóriát a városhálózaton belül, sőt ebből a csoportból még kiválik egy másik, kiemelkedő mutatókkal rendelkező szük városkör, amely bizonyos - innovációt támogató - intézményi hátterének köszönheti helyzetét.

Ezeknek a tényezőknek köszönhető, hogy a városoknak csak egy szűk köre, mintegy negyede kerül a teljes átlag fölé. Míg az ettől elmaradók nagy része egy viszonylag homogén tömböt alkot, kevéssel az átlag alatti pontszámokkal, a két fókomponens esetében a pontszámok minimuma nem éri el az egy szórásnyi negatív távolságot, ami elsősorban a sok nulla értékủ mutatónak köszönhető. Annak a hátterében, hogy mind a humánerőforrás, mind pedig az innovációs főkomponens esetében jelentősen magasabb az eloszlás csúcsosságának értéke az előző vizsgálattal összehasonlítva, részben az áll, hogy jelen vizsgálat nagyobb elemzési körrel dolgozik; a városhálózat 2004 utáni „új belépői” túlnyomó többséggel nem mutatnak érdemleges teljesítményt ebben a két dimenzióban. 
Jelentős mértékben - 251-ről 327-re - növekedett a vizsgálati egységek száma, körükben több indikátor nulla értékkel lép be a modellbe.

Összességében elmondható, hogy az alapvető társadalmi-gazdasági indikátorok alapján egy jól kezelhető fejlett-fejletlen hierarchiát azonosíthattunk, de a versenyképesség és az innovativitás mutatóinak eloszlása egyensúlytalan lett. Emiatt, illetve a mérsékelt innovációval rendelkező városok száma miatt nem tudunk kellöen megalapozott kijelentéseket tenni a K+F+I-potenciál, valamint a gazdasági folyamatok közötti kétirányú pozitív kapcsolatokról a vizsgálat e szakaszában.

Amennyiben a tematikus főkomponensek segítségével osztályozást kívánunk végezni, mindenképpen meg kell vizsgálnunk a dimenziók közötti kapcsolatokat. A főkomponensek páronkénti korrelációi minden esetben szignifikánsak, de a kapcsolatok erőssége változó (3. táblázat).

3. táblázat. A főkomponensek közötti páronkénti korrelációs együtthatók Bivariate correlation coefficients between principal components

\begin{tabular}{lcccc}
\hline & Gazdaság & Iskolázottság & Társadalmi aktivitás & Humánerőforrás \\
\hline Iskolázottság & 0,748 & & & \\
Társadalmi aktivitás & 0,704 & 0,754 & & \\
Humáneróforrás & 0,418 & 0,569 & 0,592 & \\
Innováció & 0,375 & 0,483 & 0,516 & 0,830 \\
\hline
\end{tabular}

Az első három, normálishoz közeli eloszlást mutató főkomponens páronkénti korrelációi magasak, de a humánerőforrás és az innovációs főkomponensekkel való kapcsolatuk csak közepes erősségü. Ebből következik, hogy a főkomponensek két csoportját nemcsak eloszlási tulajdonságaik, hanem bizonyos mértékben az eltérő belső hierarchia mentén is elválaszthatjuk egymástól. Még inkább erősíti ezt, hogy a legmagasabb korrelációs együtthatót a humánerőforrás és az innováció főkomponensei között találhatjuk. Fenntartva és figyelembe véve e megosztottságot, a szignifikáns kapcsolatok alapján mégis elmondhatjuk, hogy alapvetően konzisztens mutatókészletről beszélhetünk, amely lehetőséget nyújt a városhálózat elemeinek osztályozására a társadalmigazdasági, illetve innovációs indikátorokon keresztül.

\section{A főkomponensek hálózatalakítása}

A gazdasági fókomponens pontszámai alapján való eloszlás egyenletes, átlag feletti pontszámmal 169, átlag alattival 158 város rendelkezik. A szórástávolságon kívül eső egységek eloszlása is egyenletes, egy szórástávolságon felül 52, alul 53 város található, a két szórástávolságon kívüli egységek száma nyolc, illetve hat. Amennyiben méret és jogállás szerint vizsgáljuk a gazdasági teljesítmény mutatóit, elmondható, hogy a főkomponenshez tartozó átlagos pontszám a népesség növekedésével emelkedik. Míg az alsó kvintilisbe tartozó városok átlagos 
népességszáma 6 253, addig a felső esetében már 28337 lakos az átlag. Hasonló a helyzet abban az esetben is, ha az átlag alatti, illetve feletti pontszámmal rendelkező városok népességét vizsgáljuk.

Funkciók alapján azt tapasztalhatjuk, hogy a 23 megyei jogú város közül két város (Hódmezővásárhely, Salgótarján) produkál átlag alatti pontszámot, a többi 21 nemcsak a teljes átlag felett, hanem a felső két kvintilis valamelyikében található, közülük 11 város van az egyszeres pozitív szórástávolság felett.

A gazdasági fejlettség rangsorának legszűkebb elitje, a két pozitív szórástávolságon kívül eső nyolc város között nem találhatók megyei jogú városok. Négy, budapesti agglomerációhoz tartozó település (Budaörs, Százhalombatta, Törökbálint, Szentendre) mellett két olyan ipari központ (Paks, Tiszaújváros) sorolódott ide, amelyek gazdaságát egy-egy domináns nagyüzem határozza meg. Továbbá két olyan, 5000 lakos alatti település (Répcelak, Bábolna) került előkelő pozícióba, ahol kimondottan kedvezőek a foglalkoztatási mutatók. Az 52, egy pozitív szórástávolságon kívül eső pontszámú városok túlnyomó többsége a budapesti agglomerációban és a Dunántúlon helyezkedik el, kivételt a már említett Tiszaújvároson kívül néhány megyei jogú város (Kecskemét, Eger, Szolnok), továbbá a Budapesttől ugyancsak viszonylag kis távolságra fekvő Hatvan és Rétság képez. A Dunántúl 13 megyei jogú városa közül nyolc tartozik ebbe a körbe.

Az átlag alatt teljesítő városok köre viszonylag jól lehatárolható térségi és népességi szempontok alapján. A két megyei jogú városon (Hódmezővásárhely, Salgótarján) kívül mindössze két, 25000 főnél népesebb település (Hajdúböszörmény, Ózd) került ide. Az átlag alatt teljesítő városok átlagos lakónépessége 8403 fö, az átlag felettieké 22908 fó. Viszonylag kevés dunántúli település szerepel az átlag alatti gazdasági teljesítményű városok között, ezek túlnyomó többsége a Dél-Dunántúlon helyezkedik el. A gyenge gazdasági teljesítményt nyújtó, egy szórásnyi negatív távolságon kívül eső 53 város között mindössze három dunántúli, hátrányos helyzetű térségben elhelyezkedő, alacsony népességü település (Gyönk, Nagybajom, Kadarkút) található. A gazdasági rangsor sereghajtói, a kétszeres negatív szórástávolságon kívül eső hat település közül öt Szabolcs-Szatmár-Bereg megyében helyezkedik el.

Az iskolázottság és menedzsment fókomponensnél szintén a normálishoz közeli eloszlással találkozhatunk, 150 átlag feletti, illetve 177 átlag alatti várossal. A főkomponens pontszámaiban és kategóriáiban a gazdaságihoz képest erősebben mutatkozik a népesség és a funkció szerinti polarizáció. Az átlag alatt teljesítő városok átlagos lakónépessége 7979 fö, az átlag felettieké 25247 fö. Ugyanezek az értékek az alsó és felső kvintilis esetében 5 923, illetve 38908 föt tesznek ki. Nincs olyan megyei jogú város, amely átlag alatti pontszámmal szerepelne, és mindössze öt 25000 fö feletti népességű település (Ajka, Hajdúböszörmény, Komló, Ózd, Szentes) került ebbe a kategóriába. Az „elitet” alkotó, pozitív szórástávolságon kívül eső kategóriába került 58 város közül 17 megyei jogú, ez azt jelenti, hogy csak hat megyei jogú város (Sopron, Salgótarján, Dunaújváros, Nagykanizsa, Tatabánya, Hódmezővásárhely) sorolódott e körön kívülre. 
A regionális eloszlás is árnyaltabb a gazdasági főkomponenshez képest. A Dunától keletre fekvő megyei jogú városok túlnyomó többsége is bekerült az elitbe, viszont rajtuk kívül mindössze három város (Baja, Felsőzsolca, Gyula) tartozik ide az Alföldről és Észak-Magyarországról. A legszükebb elitet - kétszeres pozitív szórástávolság felett - alkotó kilenc város közül hét a budapesti agglomerációhoz tartozik, kivételt csak Hévíz és Balatonföldvár képez. Általánosságban is elmondható, hogy a Balaton környéki települések szignifikánsan jobban teljesítenek itt, mint a gazdasági főkomponens esetében. Balatonföldváron kívül Balatonalmádi, Balatonfüred, Keszthely, Siófok és Zamárdi is az első ötven város között van, míg gazdasági tekintetben ezt nem lehet elmondani róluk. Hasonló tendenciákat láthatunk más olyan településeken is, amelyekben domináns az idegenforgalom (Harkány, Velence, Zalakaros).

A gyengén teljesítő városok köre némileg kiegyensúlyozottabb regionálisan, mint a gazdasági főkomponensnél. Az 50, negatív szórástávolságon kívül elhelyezkedő város közül hét (Ács, Beled, Berhida, Devecser, Enying, Jánossomorja, Pusztaszabolcs) található a Dunántúlon, de közülük egy sem a Dél-Dunántúlon. A leggyengébben teljesítő városok túlnyomó többsége az Észak-Alföldön helyezkedik el (a 20 legalacsonyabb pontszámmal rendelkező város közül 14 található ebben a régióban), viszont mindössze egy település (Cigánd) kerül a kétszeres negatív szórástávolságon kívülre.

A társadalmi aktivitás fókomponensnél sem találkozhatunk extremitásokkal. Itt is a normálishoz közelít az eloszlás, a relatíve nagyobb terjedelem egyetlen város (Kiskőrös) kiemelkedő pontszámának köszönhető. A település népessége és a funkciók hasonló mértékben tekinthetők befolyásoló tényezőnek, mint az előző két főkomponens esetében. Az átlag alatti pontszámmal rendelkező városok átlagos népessége 8000 alatti, az átlag felettieké 25000 feletti, a pozitív szórástávolságon kívül eső 54 város átlagos népessége 43000 felett van. Az iskolázottsági fókomponenshez hasonlóan itt sem találunk olyan megyei jogú várost, amely átlag alatt teljesít, és mindössze két, 25000 fö feletti népességü településről (Ózd, Hajdúböszörmény) mondható ez el. A megyei jogú városok közül három (Tatabánya, Hódmezővásárhely, Érd) maradt ki a főkomponens „elitjét” alkotó, pozitív szórástávolságon túli 54 település közül.

A regionális eloszlásról elmondható, hogy a dunántúli és a budapesti agglomerációban tömörülő városok dominálnak a jól teljesítő városok körében, de kissé árnyaltabb a kép, mint az előző két főkomponensnél. Egy alföldi város, Kiskőrös rendelkezik a kiugróan legmagasabb pontszámmal, rajta kívül még három olyan található a pozitív szórástávolság felettiek között, amely nem a Dunántúlon vagy a budapesti agglomerációban fekszik, illetve nem megyei jogú város (Gyöngyös, Balassagyarmat, Tiszaújváros). A rosszul teljesítő városok valamivel kiegyensúlyozottabb térségi megoszlásáról beszélhetünk, erősebb hatást gyakorol a település nagysága és a várossá nyilvánítás időpontja. A leggyengébben teljesítő 58 város átlagos népességszáma alig haladja meg a 6000 főt, illetve elvétve található köztük olyan település, amely az ezredforduló előtt nyert volna városi rangot. 
A humánerőforrás fókomponens egyenlőtlen eloszlású: a városhálózat kiemelt csoportja jól teljesít a főkomponenst alkotó mutatókban, míg a városok többsége egymás közelében csoportosul, kevéssel átlag alatti pontszámmal. Ez részben annak a körülménynek köszönhető, hogy a fókomponensben abszolút mutatók szerepelnek, részben pedig a felsőoktatási intézmények hiánya miatt sok a nulla (nemleges) értékű alapadat. Ettől függetlenül a kapott kép valósnak tekinthető, amennyiben adottnak tekintjük a felsőoktatási és a K+F+I-infrastruktúra jelenlétének versenyképességre gyakorolt hatásait. Ennek következtében egy csúcsos, nagy terjedelmű eloszlással találkozunk, amelyet a felfelé kilógó városok határoznak meg.

Mindössze 75 várost találhatunk átlag feletti pontszámmal, a legjobban a nagy egyetemi központok teljesítenek, így az elitbe kerülnek azok a kisebb települések is, ahol méretükhöz és gazdasági súlyukhoz képest hangsúlyos a felsőoktatás jelenléte (Gödöllő, Keszthely). A magas pontszámmal rendelkező városok között atipikusnak számít Martonvásár, a felsőoktatási intézménnyel nem rendelkező városok között előnyös helyzetben vannak a budapesti agglomeráció gazdaságilag erősebb települései. A lakónépesség alapján a megoszlás polarizáltabb, mint az előző három főkomponens esetében; a legnagyobb városok az elitbe tartoznak, a nyolc, 100000 fönél népesebb település közül a leggyengébben teljesítő Kecskemét is a 17. helyen található a rangsorban. Mivel az átlag alatti pontszámok szórása viszonylag alacsony, ezért nem túlzottan hangsúlyos a kelet-nyugat differencia a rangsor negatív oldalán, ennél jobban követhető a település népességének hatása.

Az innovációs fókomponens esetében még egyenlőtlenebb eloszlásról beszélhetünk, a nagy egyetemi központok erőteljesebben kiemelkednek. Bár az átlag felett teljesítő városok száma magasabb, mint a humánerőforrás főkomponens esetében, de a szük elit még inkább elkülönül, és mind a terjedelem, mind az eloszlás csúcsossága jelentős. A humánerőforrás főkomponenshez hasonlóan ebben az esetben is jelentős az „üres” mutatók és esetek száma, a felhasznált indikátorok alapján nem vagy csak kismértékben értékelhető városok széles köre határozza meg az eloszlási sajátosságokat.

A településnagyságban a polarizáció ennél a főkomponensnél a legjelentősebb, a pozitív szórástávolságon túli 24 város átlagos népessége meghaladja a 85000 főt, a felső kvintilisbe tartozóknál is 47000 az átlagérték. A lakónépesség és a faktorpontszám közötti korreláció kiemelkedően magas $(0,956)$, ez az érték az első három főkomponens esetében mindenhol 0,5 alatt marad (bár a kapcsolatok minden esetben szignifikánsak). A megyei jogú városok mindegyike átlag feletti pontszámmal rendelkezik, a legfelső kvintilisbe tartozik. Mindössze négy megyei jogú város (Hódmezővásárhely, Szekszárd, Nagykanizsa, Salgótarján) nem került a 24 várost tartalmazó elitkategóriába. Az öt nem megyei jogúként az elitbe kerülő város mindegyike a budapesti agglomerációban található (Budaörs, Dunakeszi, Gödöllő, Szentendre, Szigetszentmiklós). Az átlag alatt teljesítő városok közül csak három (Ajka, Várpalota, Vecsés) népessége haladja 
meg a 20000 föt, az átlag felettiek között mindössze két 10000 alatti népességgel rendelkező város (Kunszentmiklós, Szeghalom) található.

\section{Az innovációs klaszterek}

A főkomponens-pontszámok alapján meghatározott fejlettségi mutatókra alapozva első lépésben átlagalapú klaszteranalízist végeztünk, így kijelöltük a kutatásunk szempontjából kiemelt, részletesebben is bemutatandó „elitkategóriát”. A főkomponensek felhasználásával végzett eljárásban, négy klaszter elkülönítését követően két kiugró csoportot kapunk, amelyek együttesen 25 várost tartalmaznak. Ezekre a városokra hierarchikus klaszterelemzést végeztünk annak érdekében, hogy a legjobban teljesítő városok mezőnyén belül típusokat, innovációs csoportokat határozzunk meg. Az 1. ábrán látható az eljárás dendrogramja, amely bemutatja a csoportképződés lépéseit, a belső tagozódást.

A 23 megyei jogú városból 17 szerepel ebben a kategóriában, Békéscsaba, Érd, Hódmezővásárhely, Nagykanizsa, Salgótarján valamint Tatabánya marad ki (a 2005-ös vizsgálatban ugyancsak 17 megyei jogú város került be az akkor 22 települést tartalmazó elitkategóriába, a kimaradók egy kivétellel megegyeznek; Békéscsaba helyett Dunaújváros került be az új modellbe). A nyolc nem megyei jogú város között egyrészt egyetemi központok (Gödöllő, Keszthely, Gyöngyös), másrészt a budapesti agglomeráció gazdaságilag jól teljesítő városai (Budakeszi, Budaörs, Szentendre, Vác) jelentek meg. A nyolcadik település az MTA kutatóközponttal rendelkező Martonvásár. A 2005-ös vizsgálathoz képest itt sem történt jelentős változás, mindössze annyi történt, hogy az ott szereplő hat városhoz csatlakozott Vác és Martonvásár.

A kiemelkedő adottságokkal rendelkező városokból képzett csoportok jellegét és sorrendjét a tényezőcsoportok eltérései határozzák meg, magyarázatot adva a fejlettségbeli különbségekre, azok tartalmára (4. táblázat).

Az első klaszterbe a komplex szerkezetü regionális központok tartoznak, ezt a négy - humán és innovációs szempontból kiemelkedő adottsággal rendelkező - nagycentrum alkotja. A 2005-ben végzett elemzéshez képest annyi változás történt, hogy Miskolc új tagként jelent meg. Ezek a városok jelentős felsőoktatási központok, így kedvezőek az innovációs mutatóik. Gazdasági teljesítményük viszonylag gyenge, Miskolc még inkább kilóg lefelé, hiszen a 25 kiugró város közül a legkedvezőtlenebb gazdasági potenciállal rendelkezik. A városok közös tulajdonsága, hogy regionális centrumok, a magyar városhálózat alakító központjai, erős innovációs potenciállal (kutatás-fejlesztés, innovációs intézmények), a kvalifikált humán tőke magas koncentrációjával, kedvező foglalkoztatási és iskolázottsági adatokkal. Fontosnak tartjuk megemlíteni, hogy az elemzés alapján Debrecen különválik a másik három várostól, akár önálló klaszterként is tekinthetünk rá. 
1. ábra: A 25 kiugró város klaszterstruktúrája a tematikus főkomponensek alapján Hierarchical cluster structure of prominent cities based on principal components

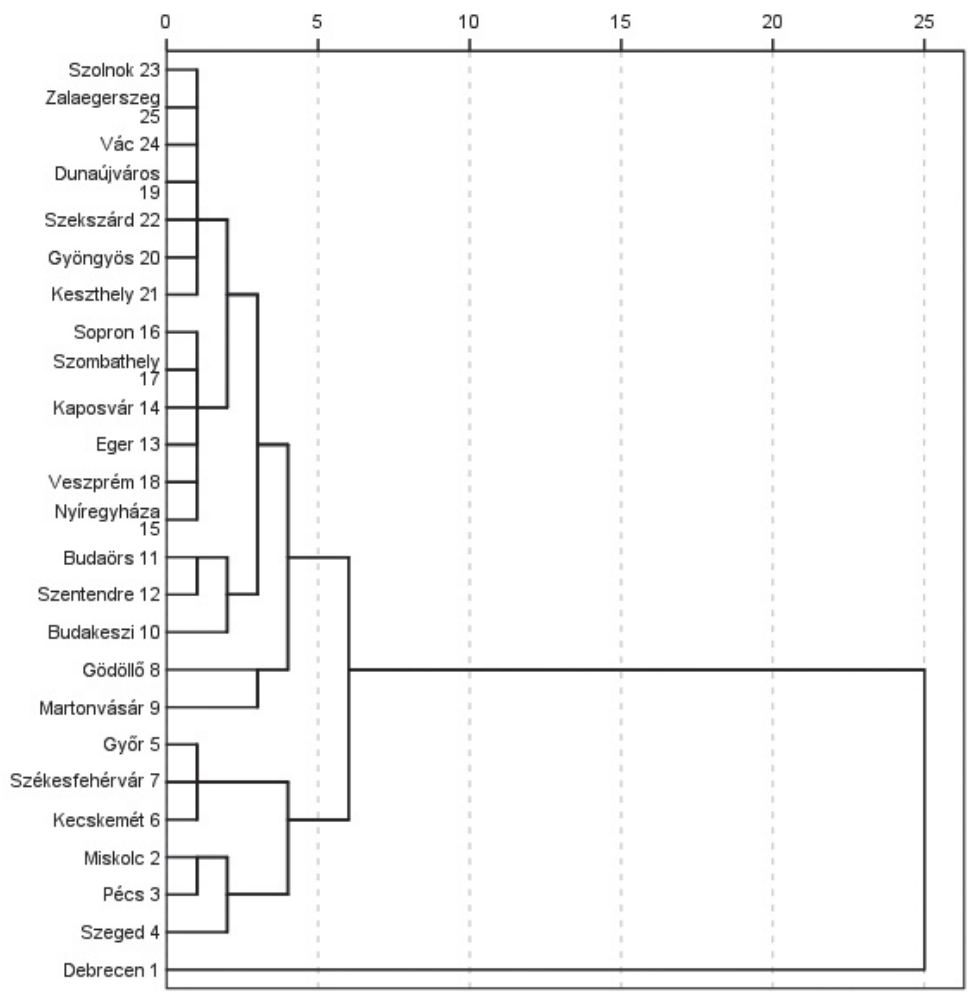

4. táblázat: Innovációs klaszterek a 25 kiugró városon belül Potential innovation clusters among the 25 prominent cities

\begin{tabular}{|c|c|c|c|c|c|c|}
\hline \multirow[t]{9}{*}{ Fókomponensek } & \multicolumn{6}{|c|}{ Fókomponens-átlagok } \\
\hline & 1. klaszter & 2. klaszter & 3. klaszter & 4. klaszter & 5. klaszter & 6. klaszter \\
\hline & Debrecen & Győr & Gödöllő & Budakeszi & Eger & Vác \\
\hline & Pécs & Székesfehérvár & - Martonvásár & Budaörs & Veszprém & Szolnok \\
\hline & Szeged & Kecskemét & & Szentendre & Sopron & Szekszárd \\
\hline & Miskolc & & & & Nyíregyháza & Keszthely \\
\hline & & & & & Szombathely & Dunaújváros \\
\hline & & & & & Kaposvár & Gyöngyös \\
\hline & & & & & & Zalaegerszeg \\
\hline Gazdaság & 0,69 & 1,59 & 1,37 & 2,18 & 1,14 & 1,12 \\
\hline Iskolázottság & 1,67 & 1,55 & 1,70 & 3,02 & 1,40 & 1,34 \\
\hline Társadalmi aktivitás & 1,92 & 1,70 & 1,17 & 1,90 & 1,95 & 1,63 \\
\hline Humánerőforrás & 5,34 & 2,67 & 4,81 & 1,29 & 2,93 & 1,78 \\
\hline Innováció & 6,47 & 4,02 & 0,55 & 1,28 & 1,98 & 0,94 \\
\hline
\end{tabular}


A második, komplex szerkezetü regionális központok erős gazdasági potenciállal nevü klaszter tagjai is kiugró paraméterekkel büszkélkedhetnek, és kivételes gazdasági teljesítményt képesek felmutatni. A humánerőforrás és az innovativitás mutatói ugyan a kiemelt csoporton belül is átlag felettiek, de szignifikáns lemaradás mutatkozik az első klaszterhez képest. A humánerőforrás-állomány mutatói javuló tendenciát jeleznek a 2005-ös vizsgálathoz képest.

A harmadik, kutatás-fejlesztés- és felsőoktatás-orientált klasztert Gödöllő és Martonvásár alkotja. Stabil, átlaghoz közeli mutatókkal rendelkeznek, egyetlen érték kiemelkedő: a humánerőforrás. Elsősorban a martonvásári akadémiai kutatóközpont jelenlétével és a gödöllői egyetemmel magyarázható, hogy bekerültek az elitklubba, s ott önálló csoportot képeznek. Innovációs képességük mérsékelt a többi kiemelt városhoz képest, de a kutatás-fejlesztési aktivitás kiemelkedő, az első klaszter városaihoz hasonló. (E megállapítás a kutatásba bevont adatok alapján érvényes, nem veszi figyelembe a tényleges kutatási eredményeket, például a publikációkat, szabadalmakat, az alkalmazott eljárások bevezetését, az eredményeket. A Martonvásáron lévő akadémiai kutatóközpont a hazai és a nemzetközi agárkutatás egyik központja, a Szent István Egyetem Gödöllőn számottevő kutatási eredménnyel rendelkezik, sajnos ezeket nem regisztrálhattuk az elemzésekben.)

A negyedik klaszter a budapesti agglomeráció gazdasági alközpontjai: Budakeszi, Budaörs és Szentendre. Jelentős gazdasági potenciállal rendelkeznek, az iskolázottsági főkomponens paramétere kiugró, messze elkülönül a többi kiemelt várostól. Kedvező adottságaikat a főváros közelségével magyarázhatjuk, de innovációs potenciáljuk az előbb említett mutatókhoz képest mérsékeltebb.

Az ötödik klasztert a jelentős felsőoktatási-humán bázissal rendelkező városok alkotják (Eger, Veszprém, Sopron, Nyíregyháza, Szombathely, Kaposvár), ezek közül Eger és Veszprém kiemelkedik, mert az elmúlt évek során ugrásszerü fejlődési pályát írt le. Stabil, középmezőnyhöz tartozó városok, azonban innovációs és humánerőforrás-állományukban súlyponti szerepet még nem tudnak betölteni. Eltérő pozícióból közeledtek egymáshoz az elmúlt években. A klaszter legkiemelkedőbb paramétere a humánerőforrás fökomponens, amelyet a felsőoktatási intézmények jelenléte magyaráz. A 2005-ös kutatáshoz képest emelkedik az innovációs rátájuk. Szombathely, Nyíregyháza és Sopron gazdasági szerepe csökkenő tendenciát mutat.

A hatodik klaszter - térségi központok vegyes (felsőoktatási, gazdasági) orientációval - a mutatók átlagait tekintve a legalacsonyabb értékeket hozza. Az innovációs potenciál a többi csoporthoz képest kimondottan alacsony, e középvárosoknál (három megyeszékhely, három térségi felsőoktatási központ és egy fővárosi agglomerációs központ) nem beszélhetünk hálózatalakító funkciókról, de térségi központoknak tekinthetjük őket. A kiugró értékeket esetükben a humánerőforrás-állomány képviseli, de összességében meglehetősen átlagos pa- 
raméterek jellemzik a városcsoportot, ahol az újító célzatú kezdeményezések száma alacsony, gyenge az innovációs potenciál.

A 2005-ös vizsgálathoz viszonyítva a klaszterek fókomponens-átlagpontszámairól elmondható, hogy az első klaszter gazdasági potenciálja és iskolázottsági mutatója visszaesett (2005-ben ez sorrendben 1,01 és 2,02 volt). Ennek fó oka, hogy míg 2005-ben Miskolc a második klaszterbe tartozott, most bekerült az elsőbe. A társadalmi aktivitás és az innovációs mutató javult. A klaszteren belül a legkiugróbb értékkel a humánerőforrás-potenciál mutatószáma rendelkezik, ez 2005-ben 4,54 volt, mára 5,34-re növekedett.

A második klasztert a 2005-ös vizsgálatban Miskolc és Nyíregyháza alkotta, ehhez képest Miskolc ma már az első, Nyíregyháza viszont az ötödik klaszterbe sorolható. Tehát a második csoportot alkotók kicserélődtek, ennek köszönhetően a fókomponensek átlagai is változtak. Az ide sorolt városok teljesen megegyeznek az előző kutatás harmadik klaszterével, így ez jelent összehasonlítási alapot. A gazdasági potenciál kissé visszaesett (1,69-ről a jelenlegi 1,59-re), ezen kívül az összes mutató pozitív irányba mozdult.

További, jól összehasonlítható csoportot alkotnak a budapesti agglomeráció városai. Jelen vizsgálatban a negyedik klasztert alkotja Budapest, Budaörs és Szentendre. Az előző vizsgálatban külön csoportként jelent meg Budaörs és Budakeszi, Szentendre azonban az ötödik klaszter egyik települését alkotta. Gazdasági és iskolázottsági mutatóik kiugróan magas értéket képviseltek az előző és a jelenlegi vizsgálatban is, azonban kissé visszaesett mind a két átlagszám. A humánerőforrás és a társadalmi aktivitás átlagértékei mára jelentősen nőttek (sorrendben 1,26 és 0,65), viszont csökkenést mutat az innovációs képességet mérö adat (2005-ben 1,75 volt).

Az ötödik klasztert jelenleg Eger, Veszprém, Sopron, Nyíregyháza, Szombathely és Kaposvár alkotja. A 2005-ös kutatáshoz képest annyi változás történt, hogy megjelent Nyíregyháza (az előzőben Miskolccal együtt alkottak egy csoportot), illetve ebbe a klaszterbe tartozott Békéscsaba is, viszont jelen kutatásban ez a település nem rendelkezett kiugró értékekkel, így az elitkategóriába nem került be. A klaszter gazdasági mutatójának átlaga jelentősen visszaesett (2005-ben 1,40 volt, jelenleg azonban 1,14). Az iskolázottsági potenciál hasonlóan alakult (0,05 az elhanyagolható különbség a két vizsgálat eredményei között). A társadalmi aktivitás átlaga kissé csökkent (2,09-ről 1,95-re). Jelentősen javult a humánerőforrás és az innovációs főkomponens klaszteren belüli átlaga.

A 25, elitnek tekintett város helyzetét a klaszterképző főkomponensek segítségével két-két dimenzióban ábrázolhatjuk. A 2. ábra vízszintes és függo"leges tengelyei mutatják a főkomponenseket, az egyes városok értékei az átlaghoz képest mért távolságot jelzik, míg a belső vonalak jelölik az adott főkomponensek átlagát. A 3. ábra a klaszterekhez tartozó városok elhelyezkedését mutatja. 

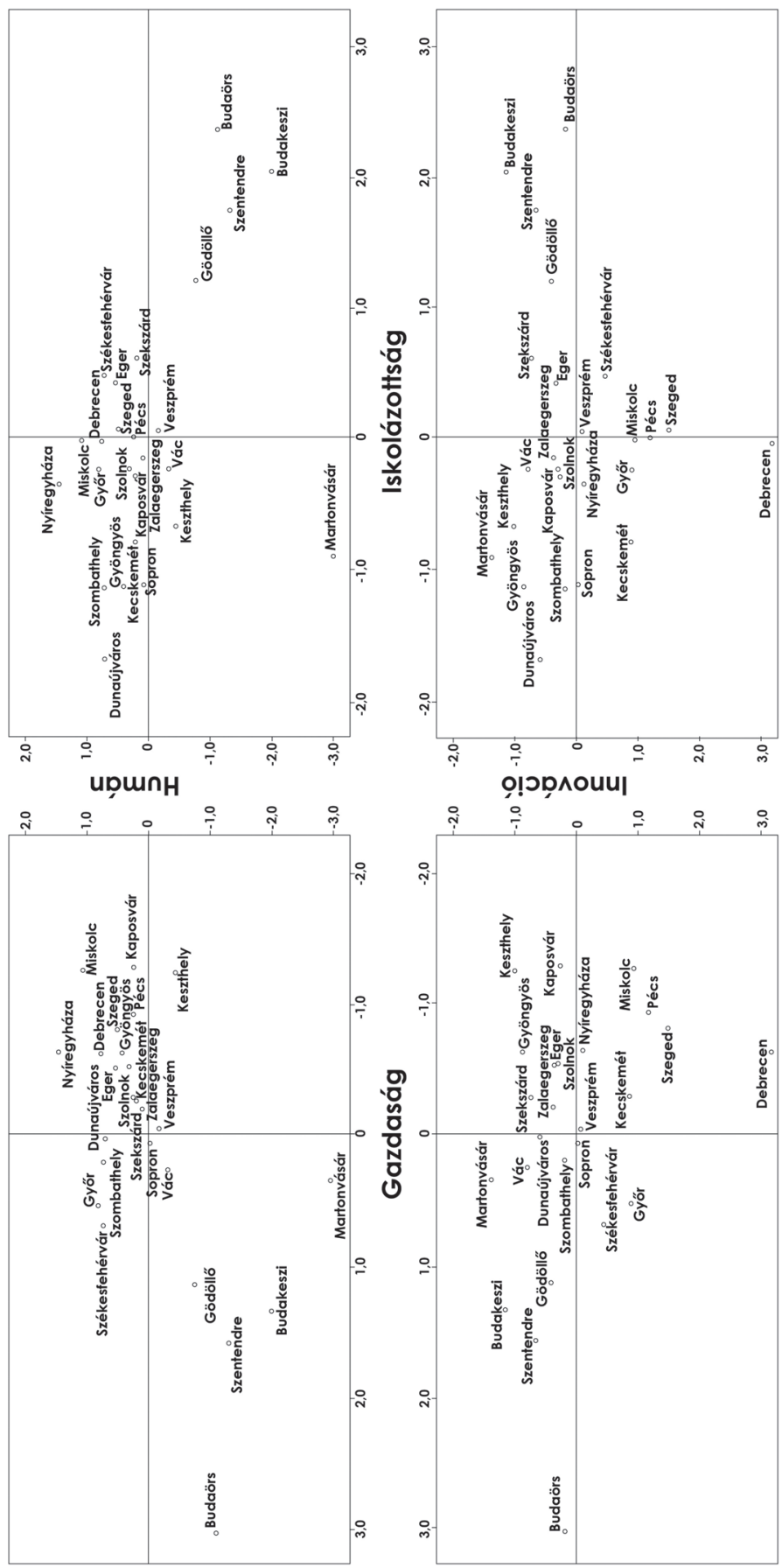
3. ábra: A 25 kiemelt város elhelyezkedése klaszterek szerint

Geographical position of the prominent cities by clusters

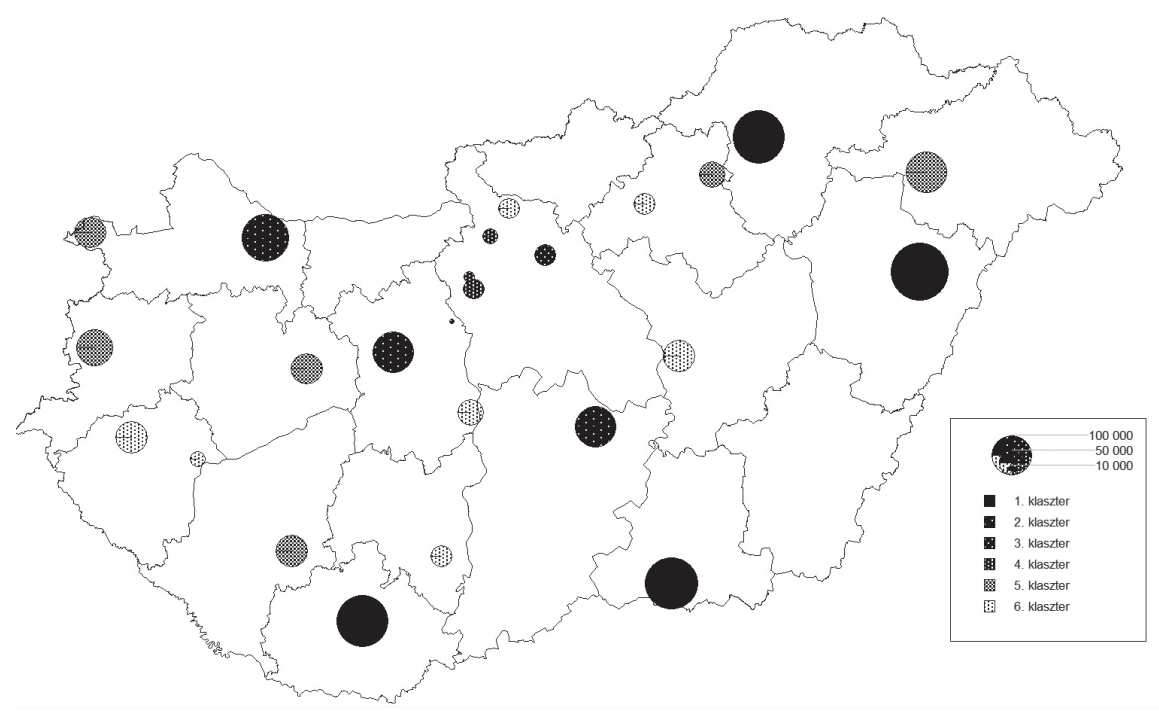

\section{Az elitklubon kívüli többi város}

A városhálózat fennmaradó tagjainak klasztereit újfent átlagalapú eljárással jelöltük ki, mivel a magas elemszám nem ad lehetőséget a hierarchikus módszer alkalmazására. A 2005-ös vizsgálathoz hasonlóan a kiugró városokat kiszürve jelentősen megnövekedik a gazdasági teljesítmény és az iskolázottsági mutatók szerepe a klaszterek kialakításában, jelezve, hogy az innováció és a kapcsolódó humán kapacitás az elitklubban koncentrálódik, $\mathrm{s}$ annak lecsorgása a városhálózat más tagjaiba nem számottevő.

A fennmaradó 302 városra a négyklaszteres bontással (7-10. klaszterek) lehet a különböző típusokat karakteresen elhatárolni (4. ábra).

Az elitkategória utáni városhalmazt (7. klaszter), az átmeneti helyzetü, de innovációs potenciállal rendelkezők csoportját 37 központ alkotja, ahol a végleges klaszterközéppontok az öt főkomponensben átlag feletti értéket mutatnak. A városhalmaz nem egységes, több alcsoportra osztható funkciók és területi elhelyezkedés alapján, ezek az alábbiak:

- az elitből kimaradó megyei jogú városok egy része (Békéscsaba, Érd, Nagykanizsa, Hódmezővásárhely), valamint néhány megyei szintű középváros, ahol a gazdasági potenciál erősebb, működik felsőoktatási intézmény (pl. Baja, Esztergom, Mosonmagyaróvár);

- a budapesti agglomeráció döntően keleti, déli felének erősödő középvárosai (pl. Dunaharaszti, Szigetszentmiklós, Veresegyház);

- a Balaton régió egymással vetélkedő centrumai (pl. Siófok, Balatonfüred, 
4. ábra. A 302 nem kiemelt város elhelyezkedése klaszterenként Geographical position of non-prominent cities by clusters

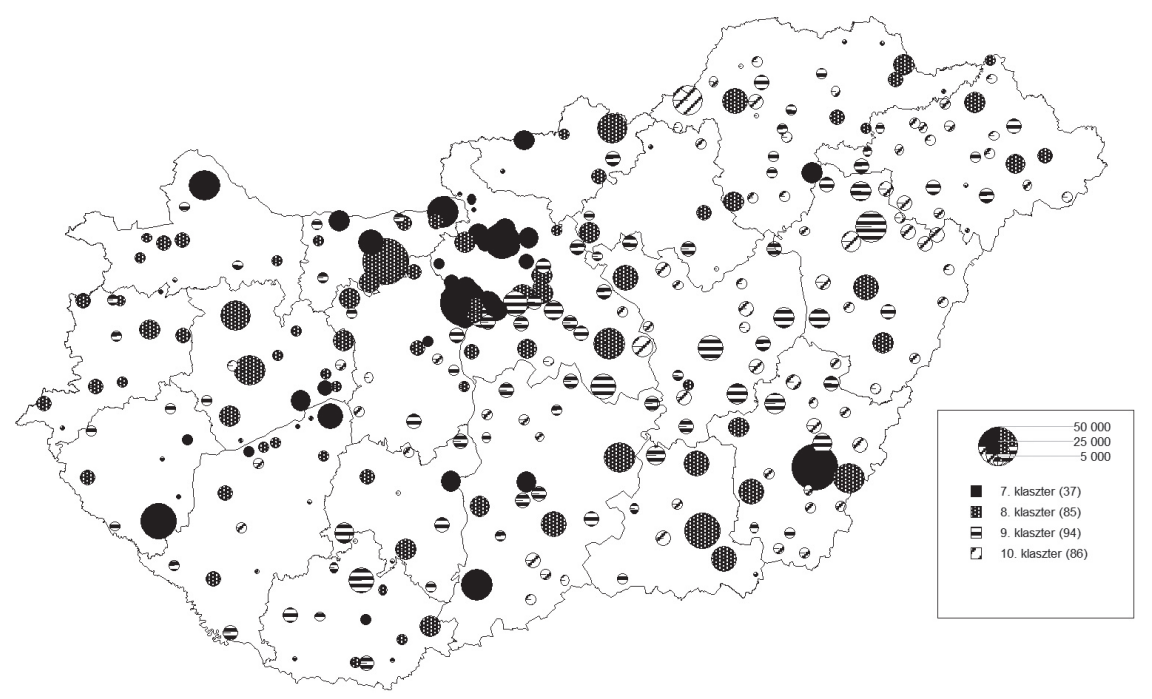

Balatonalmádi), valamint jelentős turisztikai, idegenforgalmi potenciállal rendelkező kisvárosok (pl. Velence, Visegrád, Zalakaros);

- magas gazdasági teljesítményt mutató kis- és középvárosok (Paks, Tiszaújváros).

A következő, nyolcadik klasztert, az átlagos fejlettségü, alacsony humán bázissal és innovációs potenciállal rendelkezö 85 város alkotja. Esetükben csak árnyalatnyival jobbak az átlagosnál a gazdasági és iskolázottsági mutatók. Elsősorban dunántúli kisvárosok tartoznak ide, az ország keleti részéből inkább csak néhány olyan középváros, amelyek gazdasági teljesítményük alapján nem tudtak bekerülni az átmeneti helyzetủ városok közé (pl. Gyula, Kiskunfélegyháza, Kazincbarcika). Itt található még a három leggyengébben teljesítő megyei jogú város (Hódmezővásárhely, Salgótarján, Tatabánya). Megemlíthető még az egykori ipari-energetikai tengely dunántúli iparvárosainak (Ajka, Dorog, Oroszlány, Várpalota) jelenléte, illetve az, hogy ide „csúsznak le” a budapesti agglomeráció keleti és délkeleti szektorának szerényebb gazdasági potenciállal jellemezhető városai (Gyömrő, Dabas, Vecsés, Maglód).

A kilencedik klaszterbe, az átlag alatti fejlettségü városok csoportjába 94 település sorolódott, minden dimenzióban átlag alatti teljesítménnyel. Az alföldi városok túlsúlya jellemzi a csoportot, emellett megtalálhatjuk a Dél-Dunántúl kisvárosait, valamint belső perifériaként jellemezhető térségek hosszú városi múlttal nem rendelkező központjait (pl. Adony, Ercsi, Tét). Tipikusan alacsony népességű településekről van szó, a lakónépesség átlaga alig haladja meg a 9000 föt, mindössze egyetlen 30000 fö feletti népességgel rendelkező települést (Hajdúböszörmény) találhatunk közöttük, ezen kívül csak négy város 
(Komló, Nagykőrös, Gyál, Törökszentmiklós) népessége haladja meg a 20000 fót. A 2005-ben közölt vizsgálatban két átlagos csoportot alkottunk, az egyikben a humánerőforrások és az innovációs potenciál még érzékelhető volt, de alacsony szinten, a másikban már erről sem beszélhettünk, így akkor 118 város tömörült ebbe a két csoportba.

A tizedik klaszter, a kimondottan kedvezőtlen adottságú városok, minden tekintetben mélyen átlag alatti paraméterekkel. Az ide tartozó 86 település közül tíz található a Dunától nyugatra, nagyrészt alföldi és észak-magyarországi városok alkotják a csoportot. Mindössze egy város (Ózd) népessége haladja meg a 20000 föt, a klaszterbe tartozó települések átlagos népessége 6290 fö. A klaszter 34 olyan várost - az állomány 40\%-a - tartalmaz, amelyek 2001 után kaptak városi rangot, ami szignifikánsan magasabb a többi klaszterben megjelenő új városok arányánál.

\section{A városhálózat trendjei}

A tízévente azonos szemléletben és közel megegyező adatbázissal végzett vizsgálatok a városhálózat stabilitását jelzik, amelyben kisebb elmozdulások, visszafogott átrendeződések figyelhetők meg.

Az adatbázist nem egyszerü összeállítani, alapos és gondos feltáró munka szükséges a hivatalos statisztikákat meghaladó városi információk felkutatásában. Az adatok egy része folytonos sokaságot tükröz, másik - döntően egyedi gyüjtésre épülő - halmaza csak a nagyobb centrumokban áll rendelkezésre, azaz találunk olyan tényezőket, amelyek a megújításhoz, az innovációhoz vagy az azt generáló humánerőforrásokhoz köthetők. Ez természetesen megzavarja az elemzéseket, nagy eltéréseket és különbségeket teremtve. Ennek csökkentésére törekedtünk a változócsoportok alapján történő elemzésekkel, illetve klaszterek, hasonló fejlődést mutató városhalmazok leírásával.

Az elemzésekből azt tapasztaljuk, hogy míg a gazdasági potenciál, az iskolázottság és a társadalmi aktivitás értékei egyenletes eloszlást követnek, addig erősen aszimmetrikus a humánerőforrás és az innovációs potenciál koncentrációja. Az egyenlőtlen eloszlás utóbbi két főkomponensnél odavezet, hogy a hálózat korábbi vizsgálatban is jelzett határozott elkülönülései megmaradtak, csak kisebb mértékủ elmozdulások regisztrálhatók.

A városhálózat csúcsát jelentő megyei jogú városok erősen polarizálódtak. A tradicionális nagyvárosok, a regionális központok (Debrecen, Szeged, Pécs, Miskolc) innovációs potenciálja és humánerőforrásai kiemelkednek a hálózatból, viszont gazdasági potenciáljuk kimondottan mérsékelt: sem specializációban, sem koncentrációban nem emelkednek ki. Az egyoldalas csúcs, ahol a tudástermelés kimutatható, de a gazdaság gyenge, nem számottevő, így nem kapcsolódik össze a két rendszer, a városok működését a közszolgáltatások, közintézmények 
jelenléte tartja egyben. A kiugró gazdasági potenciállal rendelkező nagyvárosok (Győr, Székesfehérvár, Kecskemét) esetében viszont az előbbieknél alacsonyabb az innovációs és humán potenciál, magas iskolázottság, kedvező foglalkoztatási viszonyok alakultak ki. Az elmúlt tíz évben sem sikerült felkúszni ezeknek a városoknak a csúcsra, nem tudtak belépni a tradicionális nagyvárosok elitcsoportjába, bár egyes mutatóikban közelítették azokat (innovációs potenciál, iskolázottság). Ha sikertörténetről beszélhetünk, az Debrecen, amely képes volt önálló fejlődési pályát bejárni, a tíz év lendületével - ha képes azt megtartani - a jövőben kiválhat a vezető csoportból, az ország második nagyvárosaként jelenhet meg. Hasonló a helyzet Miskolccal, amely felzárkózott a csúcsvárosokhoz, ezt döntően magas humánerőforrásainak és a felsőoktatásra épülő, erősödő innovációs potenciáljának köszönhette, ezzel kompenzálta viszonylag gyenge gazdasági teljesítményét.

A kiemelkedő adottságokkal rendelkező városok 25 tagot számláló csoportjába csak 17 megyei jogú város sorolódott be (68\%), a megosztott regionális központokon kívül egy-egy alcsoport alakult ki, ahol döntő fontosságú a humánerőforrás és az átlagosnál nagyobb innovációs potenciál, amelyeket a felsőoktatási bázisok teremtenek meg. A budapesti agglomeráció sajátos helyzetet mutat a városhálózatban, a csúcsvárosok között két alcsoport különül el, az egyikben a gazdasági potenciál a csoportképzés alapja, a másikban a magas gazdasági potenciál és a betelepülők kiemelkedő iskolai végzettsége.

A klaszterelemzéssel megszürt városhálózatban a fejlettséget megjelenítő csoportoknál karakteres elmozdulásokat nem tudtunk kimutatni. Az alcsoportok, egymáshoz fejlődésben közel álló városhalmazok vagy megtartják korábbi karakterüket, vagy újabb csoportok jönnek létre, amelyeket egy, jobb esetben néhány tényező determinál. Megállapítható, $s$ egyben a korábbi vizsgálat eredményeit megerősíti, hogy 50-60 városban koncentrálódnak a fejlődés, a megújulás erőforrásai, felük mozdulni képes központ, negyedük az innovációkat és a humánerőforrásokat koncentrálni és fejleszteni képes nagycentrum.

A leszakadók, lemaradók halmaza a városhálózatban folyamatosan bővül, a nem a fejlődési tényezőkre építő, térségi funkciókat támogató városfejlesztési politika az elmúlt tíz évben csak felhígította a hálózatot, reményt adva a fejlödésre, példákat nyújtva a leszakadáshoz, a mozdulatlansághoz, a szükséghez.

A magyar városhálózat időbeli összehasonlító elemzése szükséges, s egyben tanulságos. Ugyanakkor módszerében kimerült! A 10-12 nagyváros esetében nemzetközi elemzésre van szükség, legalább kelet-közép-európai összevetésre, mert igazi versenyterük ebben a makrorégióban van, s fejlesztési pályájukat a szomszédos országok nagyközpontjaihoz kell alakítani. Kívánatos lenne elemezni e városkör tagjainak egyedi fejlődési pályáit, azon kemény és puha tényezőket, intézményeket, szereplőket és kapcsolatokat, amelyek legkorábban a rendszerváltozás óta jelen vannak a nagyvárosokban. Ezekkel az elemzésekkel leírhatjuk a hazai modelleket, példát adhatunk a hálózat második körének az elmozdulásra és reményt a többségnek a megújításra. 


\section{Jegyzet}

1 A jelzett kutatásban az elemzéseket Csizmadia Zoltán végezte a városhálózat egészére, a megyei jogú városokra pedig Nárai Márta.

\section{Irodalom}

Bajmócy P., Kiss J. (1999): Megyék, régiók és központjaik - modellek tükrében. Tér és Társadalom, 1-2., 31-51.

Barta Gy. (2009): Integrált városfejlesztési stratégia: a városfejlesztés megújítása. Tér és Társadalom, 3., 1-12.

Beluszky P. (1999): Magyarország településföldrajza. Általános rész. Dialóg Campus Kiadó, Budapest

Csapó T., Kocsis Zs. (2008): A várossá válás reformja. Területi Statisztika, 6., 645-650.

Csomós Gy. (2013): Magyarország gazdasági központjainak pozícióváltása. Területi Statisztika, 6., 529-550.

Dövényi Z. (2009): „Város az, ami magát annak nevezi.” Tűnődések Tóth József tanulmánya alapján. Területi Statisztika, 1., 3-7.

Enyedi Gy. (2010): Városok a közép-európai átmentben. In: Barta Gy., Beluszky P., Földi Zs., Kovács K. (szerk.): A területi kutatások csomópontjai. MTA RKK, Pécs, 223-243.

Enyedi Gy. (2012): Városi világ. Akadémiai Kiadó, Budapest

Faragó L. (2006): A városokra alapozott területpolitika koncepcionális megalapozása. Tér és Társadalom, 2., 83-102.

Faragó L. (2008): A funkcionális városi térségekre alapozott településhálózat-fejlesztés normatív koncepciója. Falu-Város-Régió, 3., 27-32.

Faragó L. (2009): A településhálózat és annak alakítása (A városokról való diskurzus folytatása). Területi Statisztika, 3., 257-263.

Grosz A., Rechnitzer J. (szerk.) (2005): Régiók és nagyvárosok innovációs potenciálja Magyarországon. MTA RKK, Pécs, Győr

Horváth Gy. (1998): Az átmenet regionális hatásai Kelet-Közép-Európában. Területi Statisztika, 4., 295-318.

Horváth Gy. (2007): Régióközpontok Európában. Magyar Tudomány, 6., 704-721.

Horváth Gy. (szerk.) (2006): Régiók és települések versenyképessége. MTA RKK, Pécs

Kulcsár J. L. (2008): Rendhagyó gondolatok a várossá nyilvánításról a megkésett fejlődés kontextusában. Területi Statisztika, 5., 509-515.

Lengyel I. (2007): Fejlesztési pólusok mint a tudásalapú gazdaság kapuvárosai. Magyar Tudomány, 6., 749-759.

Lengyel I., Rechnitzer J. (2000): A városok versenyképességéről. In: Horváth Gy., Rechnitzer J. (szerk): Magyarország területi szerkezete és folyamatai az ezredfordulón. MTA RKK, Pécs, 130-153.

Nagy G. (2011): A gravitációs modell felhasználhatóságának lehetőségei a várostérségek lehatárolásában. Területi Statisztika, 6., 656-673.

Pálné Kovács I. (2010): Városi terek kormányzása és a városi rezsimek. Egy induló kutatás margójára. Tér és Társadalom, 4., 3-27.

Pirisi G. (2009): Város vagy nem város? Dilemmák a formális és funkcionális városfogalom kettőssége kapcsán. Területi Statisztika, 2., 129-136.

Pirisi G., Trócsányi A. (2009): Így készül a magyar város. Területi Statisztika, 2., 137-147.

Rechnitzer J. (1993): Szétszakadás vagy felzárkózás. A térszerkezetet alakító innovációk. MTA RKK, Győr

Rechnitzer J. (2007): Az európai regionális politika és a városfejlődés. Magyar Tudomány, 6., 692-704.

Rechnitzer J., Csizmadia Z., Grosz A. (2004): A magyar városhálózat tudásalapú megújító képessége az ezredfordulón. Tér és Társadalom, 2., 117-156. 
Salamin G., Radvánszki Á., Nagy A. (2008): A magyar településhálózat helyzete. Falu-Város-Régió, 3., 6-27.

Somlyódyné Pfeil E. (szerk.) (2012): Az agglomerációk intézményesitésének sajátos kérdései. Három magyar nagyvárosi térség az átalakuló térben. Publikon Kiadó, Pécs

Szigeti E. (2002): Község, város, jogállás. A magyar településhálózat közigazgatási térszerkezetének néhány kérdése. Magyar Közigazgatási Intézet, Budapest

Szirmai V. (szerk.) (2009): A várostérségi versenyképesség társadalmi tényezői. Dialóg Campus Kiadó, Budapest, Pécs

Szirmai V. (szerk.) (2013): Csinált városok a XXI. század elején. Egy „új” városfejlődési út ígérete. MTA Társadalomtudományi Kutatóközpont Szociológiai Intézete, Budapest

Tagai G. (2010): A városok szerepe a kelet-közép-európai országok térszerkezetének formálásában. In: Barta Gy., Beluszky P., Földi Zs., Kovács K. (szerk.): A területi kutatások csomópontjai. MTA RKK, Pécs, 244-260.

Tóth B. I. (2011): A magyar középvárosok teljesítménye a területi tőke tükrében. Területi Statisztika, 5., 530-543.

Tóth G., Nagy Z. (2013): Eltérő vagy azonos fejlődési pályák? A hazai nagyvárosok és térségek összehasonlító vizsgálata. Területi Statisztika, 6., 593-612.

Tóth J. (2008): Meditáció a városokról és a várossá nyilvánítás hazai gyakorlatáról. Vitairat. Területi Statisztika, 3., 237-244. 